\title{
Border closures and the externalization of immigration controls in the Mediterranean: a comparative analysis of Morocco and Turkey
}

\section{Ayşen Üstübici and Ahmet İçduygu}

\begin{abstract}
This article traces the recent history of border closures in Turkey and Morocco and their impact on human mobility at the two ends of the Mediterranean. Border closures in the Mediterranean have produced new spaces where borders are often fenced, immigration securitized, and border crossings and those facilitating border crossings criminalized. Here, bordering practices are conceptualized as physical bordering practices, border controls, and legal measures. Turkey and Morocco constitute comparable cases for an analysis of border closures insofar as they utilize similar mechanisms of closure, despite having quite different outcomes in terms of numbers. The article's findings are based on fieldwork conducted at both locations between 2012 and 2014, as well as on analysis of Frontex Risk Assessment Reports from 2010 to 2016. The first part of the article reflects on the concepts of border closure and securitization, together with their implications, and draws for its argument on critical security studies and critical border studies. The second part of the article is an overview of controls over mobility exercised in the Mediterranean from the 1990s onward. Then, in the third and fourth parts, we turn to the particular cases - respectively, Turkey and Morocco-in order to discuss their processes of border closure and the various implications thereof. Through analysis of the two country cases, we show that border closures are neither linear nor irreversible.
\end{abstract}

\footnotetext{
Ayşen Üstübici, Department of International Relations, Koç University, 34450, Sarıyer, İstanbul, Turkey, austubici@ku.edu.tr.

Ahmet İçduygu, Department of International Relations, Koç University, 34450, Sarıyer, Istanbul, Turkey, aicduygu@ku.edu.tr.

Authors' note: The authors gratefully thank three anonymous reviewers for their constructive comments. We also thank Judy Woods for her assistance with desktop research and language editing.
} 
Keywords: externalization of border and migration policies; border closures; Mediterranean; Turkey; Morocco

\section{Introduction}

As the European Union's (EU) interest in controlling irregular flows of migration and asylum has grown, the border areas neighboring Europe have come to be shaped through various forms of border closure policies, essentially becoming "gates" filtering those who are allowed to enter and those who need to be stopped. The borders that have been subject to closure do more than simply divide two countries, such as Turkey and Greece or Morocco and Spain: they also mark the frontiers separating the EU from other regions, such as Asia and Europe and Africa and Europe. However, even in cases where the closure is deemed successful, like the Spanish enclaves bordering Morocco, occasional border "scenes" periodically revive a sense of crisis. ${ }^{1}$ In such a context, what would it take to claim that a border is closed? In other words, can border closures be absolute and permanent?

Because the Mediterranean Sea is subject to different forms of EU externalization policies, it is viewed as a European borderland and has been constructed as dangerous for migrants, despite the increasing mobility of travelers and goods thereupon. ${ }^{2}$ The relevant research has focused largely on the functioning of European borders as sites of control, and has revealed that smuggling routes shift as border closures become tighter, with the attendant scholarly discussions focusing on the implications, especially in terms of the loss of lives and smuggling in the Mediterranean. ${ }^{3}$ Despite the growing literature on the securitization of borders and the implications of this process for human security, fewer studies have looked at the nonlinear development of bordering practices, mechanisms, and the representations of closures, together with their political, economic, and social implications for countries located at the edge of Europe. In respect to border closures, what we are referring to is the tightening

1 See, for instance, "Over 180 Migrants Storm Morocco-Spain Border Post," The Hindu, August 7, 2017. http://www.thehindu.com/news/international/over-180-migrants-storm-morocco-spain-borderpost/article19446584.ece.

2 Polly Pallister-Wilkins, "The Tensions of the Ceuta and Melilla Border Fences," in EurAfrican Borders and Migration Management, ed. P. Gaibazzi, S. Dünnwald, and A. Bellagamba (New York: Palgrave Macmillan, 2017): 63-81; Didier Bigo, "Death in the Mediterranean Sea: The Results of the Three Fields of Action of European Union Border Controls," in The Irregularization of Migration in Contemporary Europe: Detention, Deportation, Drowning, ed. Yolande Jansen, Robin Celikates, and Joost de Bloois (London: Rowman and Littlefield, 2015): 55-70.

3 Alison Mountz and Jenna M. Loyd, "Constructing the Mediterranean Region: Obscuring Violence in the Bordering of Europe's Migration 'Crises', 'ACME: An International E-Journal for Critical Geographies 13, no. 2 (2014): 173-195; Bigo, "Death in the Mediterranean." 
of controls along the physical border so as to prevent irregular border crossings, such as the use of walls and fences, as well as to other securitization measures meant to make mobility more difficult and more punishable. Our understanding of nonlinearity draws attention both to interregional interactions within the Mediterranean and to the implications of border closures for shifting strategies of mobility and for institutional arrangements of closures and openings within each national context.

Countries in the Mediterranean region offer cases that are crucial for analysis of the evolution of border closures. The externalization of EU policies and the emphasis on the deterrence of irregular migration has deeply affected policies and practices regarding irregular migration in countries such as Turkey and Morocco, which share geographical borders and have close political relations with the EU. The borders between Turkey and Greece and between Spain and Morocco have long been watched over and intervened with by the EU, which has pressured both Turkey and Morocco to strengthen border management, to establish national asylum systems so as to qualify as "safe countries," and to readmit third-country nationals passing through their territory into Europe. Both countries have arguably had incentives to partly subscribe to playing the role of "transit countries"ironically, by policing EU borders against secondary irregular movements originating from sub-Saharan Africa, the Middle East, and Asia. Since the Syrian conflict and "the long summer of migration" in 2015, public attention has turned especially to the Aegean Sea. Meanwhile, our analysis suggests that these two borders - that is, Morocco-Spain and Turkey-Greece-can be compared as cases of border closures, along with different irregular migration trajectories where unauthorized cross-border movement and smuggling activities take place.

Our comparison is based on the analysis of primary and secondary sources related to borders and irregular migration produced by EU institutions and by the national governments of Turkey and Morocco. Additionally, the analysis of over 20 Frontex Risk Analysis Network Quaterly Reports and seven Annual Risk Analysis reports from 2010 to 2016 have enabled us to follow the nonlinear developments of bordering practices. Our reading of the relevant reports have focused on the assessment of the situation on what Frontex has labeled the Eastern Mediterranean route and the Western Mediterranean route. We assessed the development of border closures and the representation of these two routes in relation to other Mediterranean routes under Frontex scrutiny, such as the Central Mediterranean route, the Western Balkan route, and the Atlantic route. Our critical analysis of these documents is complemented by insights gained from the authors' own regular reporting for the OECD Continuous Reporting System on Migration (known by its French acronym, SOPEMI [Système d'observation permanente des migrations]) and from intensive fieldwork conducted in both countries between 2012 and 2014 . 
The first part of the article reflects on the concepts of border closure and securization, together with their implications. The second part of the article is an overview of controls over mobility exercised in the Mediterranean from the 1990s onward. Then, in the third and fourth parts, we turn to our particular cases in order to discuss their processes of border closure and the various implications on the institutionalization of migration controls as well as on overall mobility through Turkey and Morocco. The article shows that border closures are not linear processes of closing, but rather cycles showcasing different degrees of opening and filtering underpinned by physical and legal closures.

\section{The Mediterranean as a productive borderland: securitization, closures, risks}

Taking into account the close historical connections between the southern and northern parts of the Mediterranean, the question of where Europe's borders begin was initially answered according to cultural differences, and then later, during the Cold War, to the geopolitical limits of borders. ${ }^{4}$ The end of the Cold War gave rise to new security concerns and a new conceptualization of European borders. With the increasing securitization of migration and asylum, it has now become much more common to associate migrants with factors that undermine the social cohesion and functioning of the welfare state. ${ }^{5}$ In the context of the EU, unauthorized migration toward Europe has also been seen as a threat to the functioning of the Common Market. As a result, securitization has been coupled with an increasing politicization of international migration. ${ }^{6}$ As pointed out in the seminal work of Jef Huysmans, the elimination of internal borders was conditioned on the strengthening of external borders, and consequently, the securitization and politicization of human mobility came to justify border closures at the EU's external borders as well as beyond. ${ }^{7}$ With the securitization of migration in general, and of irregular border crossings into Europe in particular, the question of where Europe's borders begin has also been reformulated in the following way: where do the European border controls restricting human mobility start?

In the context of securitization, walls erected along EU borders symbolize "Fortress Europe." Among the prominent examples of such physical

4 Gerard Delanty, "Borders in a Changing Europe: Dynamics of Openness and Closure," Comparative European Politics 4, no. 2-3 (2006): 183-202.

5 Jef Huysmans, The Politics of Insecurity: Fear, Migration and Asylum in the EU (London and New York: Routledge, 2006).

6 For a critical review of the migration-security nexus, see Bahar Rumelili and Sibel Karadağ, "Göç ve Güvenlik: Eleştirel Yaklaşımlar," Toplum ve Bilim 140 (2017): 69-92.

7 Huysmans, The Politics of Insecurity. 
manifestations of bordering practices are the walls around the Spanish enclaves of Ceuta and Melilla, the fencing at the land border between Turkey and Greece, and the recently constructed wall on Turkey's border with Syria. As well as being defensive fortifications and territorial boundary markers signaling lines of separation, such fences and walls also need to be contextualized not only in terms of their symbolic meaning, but also in the context of wider bordering practices by taking into account their social, political, and economic implications.

This preoccupation with securing EU borders has had diverse outcomes. For one, it has created particular ways of talking about borders through border spectacles. ${ }^{9}$ Most of the media attention, for instance, has turned to such immediate spectacles as large groups on crowded boats, people climbing wire fences, and bodies washing up on shores. Such spectacles created by bordering practices reiterate a rather artificial sense of crisis, with their actual implications remaining largely out of sight. Moreover, these spectacles-along with some other manifestations of border closures-reinforce the idea that the borders have become risky. As is widely shown in the literature, rather than eradicating irregular border crossings, control measures like fences and walls have made transit movement both costlier and riskier for migrants. This process has given rise to what Ruben Andersson calls an "illegality industry," accompanied by a humanitarian industry. ${ }^{10}$ As border controls lead to more dangerous journeys for people on the move, the risks involved in crossing borders are personalized. ${ }^{11}$ Deaths in the Mediterranean Sea and elsewhere are seen by policy makers as the responsibility of the border crossers themselves. ${ }^{12}$ Integrated border management thus comes to be designed in such a way that the borders are seen as "vulnerable" while the people crossing it constitute a threat. ${ }^{13}$ Smugglers are represented as the real evil, though self-facilitated irregular border crossings in the Mediterranean are also quite common, especially along the shores between Turkey and Greece and Spain and Morocco, where the distances involved are short. ${ }^{14}$

Most analysis deals with the implications of border securitization and protection at the border and refrains from analyzing the implications beyond the border. Migrants and potential migrants on the way to Europe are affected by EU

8 Pallister-Wilkins, "The Tensions of the Ceuta and Melilla Border Fences."

9 Nicholas De Genova, "Extremities and Regularities: Regulatory Regimes and the Spectacle of Immigration Enforcement," in The Irregularization of Migration in Contemporary Europe: Detention, Deportation, Drowning, ed. Yolande Jansen, Robin Celikates, and Joost de Bloois (London: Rowman and Littlefield, 2015): 3-14.

10 Ruben Andersson, "Europe's Failed 'Fight' against Irregular Migration: Ethnographic Notes on a Counterproductive Industry," Journal of Ethnic and Migration Studies 42, no. 7 (2016): 1055-1075.

11 Bigo, "Death in the Mediterranean."

12 lbid.

13 Andersson, "Europe's Failed 'Fight'," 1061.

14 Pallister-Wilkins, "The Tensions of the Ceuta and Melilla Border Fences," 75. 
border controls even at the phase of the migration decision. ${ }^{15}$ This has been made possible due to increasing EU investment in the border infrastructure, not only in member states but also in third countries located at the EU periphery where there remain "transit migrants" who have left their country with the ultimate aim of arriving in Europe. Another priority area for EU migration management has been to invest in the legal infrastructure of third countries so as to ensure that these countries adopt a legal framework adequate for the provision of protection for migrants and refugees. As a result, restrictive policies and practices have been adopted at both border zones and "transit hubs," in the form of internal migration controls. The external dimensions of EU border policies have had a direct influence on the mechanisms of bordering and on the functioning of irregular border crossings outside European borders, as well as on the politicization and securitization of irregular migration. This process has elsewhere been conceptualized as "the international production of migrant illegality."

Taking a more comprehensive perspective that links up the place of origin, the journey, and the destination, this study suggests that border closures are never final. We should rather see borders "as disciplining entities that produce both mobility and immobility, regulating steady flows of people but also facilitating the detention and persecution of people."17 Borders function as filters: they categorize and regulate circulation by redefining what is risky from the perspective of those in power. They thus represent the tension between flows and blockage. ${ }^{18}$ Next, after first reviewing the mechanisms of control in place in the Mediterranean, this article will go on to focus on Morocco and Turkey as case studies to show the different forms into which border closures evolved and dissolved over time, as well as the kind of governing mechanisms they produce.

\section{Border closures and interactions along the Mediterranean borders}

In the late 1990s and 2000s, the diffusion of norms, laws, and institutions resulted in the tightening of EU border policies. For instance, we observe that the highest organs of the EU (such as the European Council, the Council of Ministers, the Commission, and the EU Presidency) frequently announced, as

15 Jørgen Carling and María Hernández-Carretero, "Protecting Europe and Protecting Migrants? Strategies for Managing Unauthorised Migration from Africa," The British Journal of Politics \& International Relations 13, no. 1 (2011): 42-58.

16 Ayşen Üstübici, "Türkiye'de Göç Politikaların Dönüşümü: Yasadışılığın Uluslararası Üretiminden Makbul Yabancıya?," Toplum ve Bilim 140 (2017): 106-122; Ayşen Üstübici, The Governance of International Migration: Irregular Migrants' Access to Right to Stay in Turkey and Morocco (Amsterdam: Amsterdam University Press, 2018).

17 Erella Grassiani and Michiel Swinkels, "Introduction: Engaging with Borders," Etnofoor 26, no. 1 (2014), 9.

18 Pallister-Wilkins, "The Tensions of the Ceuta and Melilla Border Fences," 64-65. 
one of their top priorities, the protection of external borders against "illegal" or irregular migration in order to ensure the internal security of the union. ${ }^{19}$ This discourse led to two different types of development. Firstly, internally, the EU made an enormous effort to establish its own aggressive new policies and institutions in order to deal with border controls and irregular flows. Secondly, externally, it attempted to force its neighbors to play an active part in combating irregular migratory flows, driven by a logic of externalization of migration control. Indeed, these trends were partly a continuation of long-established "Fortress Europe" policies. They were also partly a fresh outcome of the newly developed political climate in the context of the Eastern Enlargement, the West's fight against terrorism after 9/11, and the rising importance of migration management. ${ }^{20}$

In 1995, with the initiation of the Euro-Mediterranean Partnership-which brought together EU member states and the non-EU states of the Mediterranean Basin-migration issues became highly central to south-north relations in the region. However, such partnerships—aimed at "turning the Mediterranean basin into an area of dialogue, exchange, and cooperation guaranteeing peace, stability, and prosperity"-have rather resulted in growing misery. ${ }^{21}$ Representing the Global North, European countries have been greatly disturbed by migratory flows coming from the Global South, and in response they have formulated and implemented various restrictive immigration and asylum policies in order to control and curtail migration flows to Europe. ${ }^{22}$ These policies range from more indirect soft control measures (such as requests for visas) to direct and harder measures (such as the construction of fences along borders with non-European neighbors). It is also within this context that the EU has begun to employ a strategy of border externalization by shifting certain responsibilities for migration control to neighboring countries. ${ }^{23}$

Such attempts have required active involvement and investment by neighboring countries in connection with border controls and migration management. They are widely initiated by the EU, or by EU member states, and accompanied by a collaborative focus on pragmatic and technical cooperation.

19 See Sandra Lavenex, "Shifting Up and Out: The Foreign Policy of European Immigration Control," West European Politics 29, no. 2 (2006): 329-350; Steven Sterkx, "The External Dimension of EU Asylum and Migration Policy: Expanding Fortress Europe," in Europe's Global Role: External Policies of the European Union, ed. Jan Orbie (Aldershot: Ashgate, 2008): 117-138.

20 Johannes Pollak and Peter Slominski, "Experimentalist but Not Accountable Governance? The Role of Frontex in Managing the EU's External Borders," West European Politics 32, no. 5 (2009): 904-924.

21 Kristina Kausch and Richard Youngs, "The End of the 'Euro-Mediterranean Vision'," International Affairs 85, no. 5 (2009): 964-975.

22 Andrew Geddes, Immigration and European Integration: Towards Fortress Europe?, European Policy Research Unit Series (Manchester, UK: Manchester University Press, 1999).

23 Lavenex, "Shifting Up and Out." 
Yet they are often encumbered by sensitive issues, such as the formulation of readmission agreements and restrictive visa arrangements. Such pragmatic efforts include bilateral agreements and military border control operations between EU states and their neighbors, among them Italy and Libya, Spain and Morocco, and Greece and Turkey. In this sense, the 2004/2005 Italian-Libyan arrangements for the readmission of "illegal aliens" constitute an emblematic case study. ${ }^{24}$ Other attempts in the 2000s aimed to reactivate readmission agreements between Spain and Morocco (dating back to 1992) and between Greece and Turkey (dating back to 2002). The EU-Turkey readmission agreement of 2013 and the EU-Turkey statement of 2016 were also realized within this context of the externalization of migration control across EU geography. What has been dominating the climate of the Euro-Mediterranean Partnership is "responsibility shifting" to the Global South, rather than responsibility sharing with them. In other words, the securitization of migration has reinforced a politics of fear and exclusion. Consequently, one can observe a tension between "the rising need of dialogue, exchange, and cooperation" on the EU's part and "the declining prospect of peace, stability, and prosperity" on the part of the EU's neighbors. ${ }^{25}$

Meanwhile, on the EU side, there are also other policy issues and implementations (such as tightening visa arrangements or constructing fences or walls along borders) in whose context there is arguably little need for any cooperative exchanges with these neighbors. However, it remains questionable whether creating physical obstacles like fences or walls and increasing surveillance of the borders-which have become the most popular strategies in various parts of the EU's external borders-can function without the close cooperation of neighboring countries. Moreover, even in a cooperative context, one should still question the limits and implications of such border closure attempts.

It was as part of the rising concerns about integrated border management and the securitization of the EU's external borders that, in 2005, the European Agency for the Management of Operational Cooperation at the External Borders (Frontex) was founded. Frontex's primary activities focused heavily on Euro-Mediterranean border control, often in the form of collaborations or joint operations with EU member states. ${ }^{26}$ While regular border control is the exclusive responsibility of EU member states, Frontex's main role concentrates on the coordination of border control tasks and activities among the member states. Based on the findings of its own risk analyses, Frontex initiate joint

24 Jean-Pierre Cassarino, "Informalising Readmission Agreements in the EU Neighbourhood," The International Spectator 42, no. 2 (2007): 179-196.

25 Ahmet Içcduygu, "The Politics of Irregular Migratory Flows in the Mediterranean Basin: Economy, Mobility and 'Illegality'," Mediterranean Politics 12, no. 2 (2007): 141-161.

26 Pollak and Slominski, "Experimentalist but Not Accountable." 
operations with the participation of member states in order to prevent irregular arrivals from crossing the EU's external borders. Accordingly, since the early 2000s, a series of joint operations has been launched to control the EuroMediterranean border and to combat irregular flows. ${ }^{27}$ In other words, as Frontex "exports' risk thinking to member state agencies," the fact that borders have become riskier for irregular crossings gets construed as a sign of success. ${ }^{28}$

Neither these Frontex joint operations nor the conventional border control activities of EU member states proved fully successful at preventing, controlling, or even reducing irregular migratory flows through the Mediterranean Basin. Between 2008 and 2012, the number of detections of irregular border crossings that were registered at Europe's external land and sea borders fluctuated between 159,000 in 2008 and 72,000 in 2012, with the latter being the lowest figure recorded in the last ten years. ${ }^{29}$ After this, there was a rising trend: first to 107,000 in 2013 , which more than doubled the following year to 238,000 in 2014, and by 2015 had multiplied almost seven-fold, reaching the level of $1,827,000$ detections. The arrival of more than one million refugees and irregular migrants (mostly Syrian refugees) in various EU countries became a historical case in which the level of panic and anxiety rose tremendously. In 2016, a total of 511,000 detections of irregular border crossings were registered, indicating a more than 70 percent decline as compared to the previous year, but still marking the second highest figure recorded in recent decades.

There are fluctuations in the number of detections of irregular border crossings in each of these regions over time, but in the last couple of years there has been an overall increasing trend. In general, over the last decade, the annual number of migrants coming through the Eastern Mediterranean route, which passes through Turkey, are higher than those coming from any other route, mainly because of this route's wider neighborhood, in which large numbers of asylum seekers are originally mobilized from such fragile countries as Afghanistan, Iran, Iraq, and Syria. However, in the period of 2013-2014, the Central Mediterranean route became more active than any other route in the region (45,000 in 2013 and 170,000 in 2014), indicating that the number of irregular migrants (and refugees) mobilized primarily through Libya to Italy

27 Frontex's joint operation HERA was launched around the Atlantic border (Canary Islands) in 2006, followed by MINERVA and INDALO in the western Mediterranean region, NAUTILUS and HERMES in the central Mediterranean region, and POSEIDON in the eastern Mediterranean region and along the southeastern land border. Another joint operation called RABBIT was also operational on the land border between Greece and Turkey.

28 Andersson, "Europe's Failed 'Fight'," 1061.

29 The figures concerning the detection of irregular border crossings registered at Europe's external land and sea borders have been compiled by the authors from Frontex Annual Risk Assessment reports between 2010 and 2016. These yearly figures are based on the monthly statistics exchanged among member states and processed by Frontex. 
was sharply rising. Another visible route has been the Western Balkan route $(19,000$ in 2013, 764,000 in 2015, and 130,000 in 2016), which also often overlaps with the Eastern Mediterranean route and with circular migratory movements between Albania and Greece. In comparison, the Western Mediterranean route, which carries irregular flows mostly through the Maghreb to Spain, has been relatively less visible. The number of irregular migrants in this corridor has fluctuated between 5,000 and 10,000; there has been a notable upward trend in recent years, but still not one as high as is seen on other routes. The West African route overlaps with the Atlantic route, where mass flows to the Canary Islands may be observed, as was the case in 2006, for instance. Meanwhile, interestingly, since 2014 a new route has also been emerging along the Black Sea, within the waters of Bulgaria and Romania, thereby revealing a shift in routes due to the restrictive measures being taken along other routes. ${ }^{30}$

It is important to note here that these irregular migratory patterns are heterogeneous in terms of the drivers of migration, the origins or motivations of migrants, and the chosen routes. Looking at the recent history of the border closure policies and practices initiated by the EU in the Mediterranean requires further analysis in order to reveal the implications of and weaknesses inherit in their nature, scope, and practical implementation. As such, the following sections will shed light on the intended and unintended consequences of these emerging practices for non-EU countries around the Mediterranean Sea, taking Morocco and Turkey as specific case studies of this matter.

\section{The case of Morocco}

In the African context, Morocco represents a major example of externalization. Along with Moroccan nationals trying to cross the border irregularly, Morocco also hosts immigrants from sub-Saharan and West African countries, most of whom hope to travel on to Spain. Morocco's northern shores are only 14 kilometers from mainland Spain, separated by the Strait of Gibraltar, with Morocco's direct neighbor to the north being two Spanish enclaves on the African continent: Ceuta and Melilla. These enclaves are around 100 kilometers from the Algerian-Moroccan border, which is where most migrants enter Morocco without legal papers. The Canary Islands, one of the EU's outermost regions, can also be reached from the southern borders of Morocco, which are not clearly defined because of the political dispute over the Western Sahara. This area is thus relatively more permeable to intra-African mobility due to lax border and visa regimes. With Spain's economic growth throughout

30 Frontex, "Annual Risk Analysis 2015" (Warsaw: Frontex European Agency for the Management of Operational Cooperation at the External Borders of the Member States of the European Union, 2015). 
the 1980s, income differences across the Spain-Morocco borders have become drastic, and proximity to the EU borders, as well as the political conviction to stop transit migration, has made these borders subject to gradual closure.

Throughout the 1990s, tensions related to irregular migration have been common in Morocco's relations with Spain and the EU. Until the early 1990s, the borders around Ceuta and Melilla were fluid. Border closures began initially with the adoption of the new Spanish Law on Foreigners in 1985, and later with the coming into force of the Schengen Agreement in $1995 .^{31}$ The visa requirement led to an increase in entry through Ceuta and Melilla, which have special status outside of EU Schengen borders, and Moroccans could enter the enclaves with a valid passport for a maximum of 24 hours. $^{32}$ To prevent illegal entries by Moroccans and those of other nationalities, the Spanish government began to build fences and walls around Melilla in 1993 and around Ceuta in 1996. According to Zapata-Barrero and Witte, this was the first step toward the securitization of Spain's southern borders as a whole. Over time, the 10.5kilometer fence around Melilla and 8.2-kilometer fence around Ceuta have been upgraded and new surveillance technologies have been installed. ${ }^{33}$

As such measures were being taken around Gibraltar, Ceuta, and Melilla in the early 2000s, irregular routes shifted toward the coasts near the Canary Islands. As a result, in 2002 the SIVE (Sistema Integrado de Vigilancia Exterior) was established, covering more than 500 kilometers of Spain's southern coast; by the end of 2007 it had been extended to the Canary Islands as well. ${ }^{34}$ In response to this securitization of borders, especially around the Canary Islands, migrants started to shift the clandestine routes and engage in more coordinated attempts to cross into Melilla and Ceuta. In September and October 2005, it is estimated that 1,400 migrants attempted to cross through Ceuta and Melilla, with Moroccan security forces unlawfully removing large groups of undocumented migrants to the no-man's land between Algeria and Morocco. ${ }^{35}$ The killing of between 11 and 14 migrants, who were shot by Moroccan and Spanish border guards, in the course of just a few weeks during these attempts showed the human cost of such coercive measures. The Ceuta

31 GADEM, Migreurop, La Cimade, and APHDA, "Ceuta et Melilla: Centres de tri à ciel ouvert aux portes de l'Afrique” (GADEM 2015). http://www.migreurop.org/IMG/pdf/fr_rapportconjoint_ceutamelilla_ decembre2015.pdf.

32 Ricard Zapata-Barrero and Nynke De Witte, "The Spanish Governance of EU Borders: Normative Questions," Mediterranean Politics 12, no. 1 (2007): 85-90.

33 Ibid., 87.

34 Michael Collyer, "In-Between Places: Trans-Saharan Transit Migrants in Morocco and the Fragmented Journey to Europe," Antipode 39, no. 4 (2007): 668-690.

35 Le groupe antiraciste de défense et d'accompagnement des étrangers et migrants (GADEM), "La Chasse aux Migrants aux Frontières Sud de l'UE Conséquence des Politiques Migratoires Européennes: L'exemple des Refoulements de Décembre 2006 au Maroc" (Rabat: GADEM, 2007), 16. 
and Melilla scandal led to increasing international attention on the treatment of international migrants on Moroccan soil. Since then, coercive practices that violate national and international laws have become much more visible, and have been criticized by both domestic and international actors.

These events not only showed the human cost of border controls in the absence of fundamental rights, but they also paved the way for contestations. 2005 was a turning point for the expansion of civil society activities related to irregular migration, paving the way for the mobilization of various actors-including the migrants themselves. ${ }^{36}$ After reaching a peak in 2005-2006, there has been a decline in the number of crossings of the Morocco-Spain border. Through 2012, illegal entries into the enclaves did not exceed 2,000 per year. ${ }^{37}$ According to Frontex reports, border crossings in the Western Mediterranean route through Morocco and Algeria have stabilized at around 7,000 per year, with Moroccans themselves constituting an important portion of these crossings. ${ }^{38}$ While statistics and official data on immigration into Morocco are far from complete, estimates of the number of sub-Saharan irregular migrants between 2000 and 2010 range from 10,000 to $20,000{ }^{39}$ This means that only a minority of the immigrants in Morocco are attempting to cross the border.

Despite these declining numbers, the Spain-Morocco border continued to be subject to Frontex risk analysis and the agency's promotion of the concept of risk. ${ }^{40}$ The reports indirectly reveal that, even as the risk of irregular migration was decreasing, the actual crossing has itself become riskier for migrants. Since 2005, migrants dispersed from the borderlands around the enclaves have been camping in remote places in smaller numbers. ${ }^{41}$ Close surveillance along the border has made it impossible for small groups to gain entrance successfully. In response, migrant groups are pushed to organize among themselves and to attempt the border in greater numbers just to enable a greater chance of success. Since 2013, such "attacks" by migrants have become much more organized in the sense that migrants now gather in considerable numbers and organize a common attempt at entry.

36 Ayşen Üstübici, "Political Activism between Journey and Settlement: Irregular Migrant Mobilisation in Morocco," Geopolitics 21, no. 2 (2016): 303-324.

37 Asociación Pro Derechos Humanos de Andalucía (APDHA), "Derechos Humanos en la Frontera Sur 2009" (Seville: APDHA, 2010), 10.

38 Frontex, "Annual Risk Analysis 2016" (Warsaw: Frontex European Agency for the Management of Operational Cooperation at the External Borders of the Member States of the European Union, 2016, 16.

39 Üstübici, "The Governance of International Migration," 51.

40 Ruben Andersson, "Time and the Migrant Other: European Border Controls and the Temporal Economics of Illegality," American Anthropologist 116, no. 4 (2014): 795-809.

41 Corey Johnson and Reece Jones, "The Biopolitics and Geopolitics of Border Enforcement in Melilla," Territory, Politics, Governance 6, no. 1 (2018): 61-80. 
These border crossing attempts involve smuggling businesses operating together with other self-facilitated methods, such as groups getting together and sharing the cost of crossing. There is a chicken-egg relationship between coercive measures and mass attempts at the border in the sense that mass attempts represent a direct response to the securitization of border control, while at the same time mass attempts create a border spectacle that lays the ground for even further coercion. For instance, the eradication of wire fences pushed migrants to swim around Melilla in February 2014, resulting in casualties. ${ }^{42}$ While the number of migrants dying at the northern African border has remained relatively low, "violent attempts to cross the fence" - to use Frontex's wording-have continued since $2010{ }^{43}$

In March 2015, the legalization of pushbacks in Spain furthered the scope of border closure despite international law. ${ }^{44}$ In the meantime, it became possible for people fleeing the war in Syria to enter the enclaves through the border gate, while others crossing the fences would be pushed back. Accordingly, by mid-2015, Syrians constituted most of the arrivals in Melilla. ${ }^{45}$ Between January and June 2015, out of 4,849 total arrivals, 4,049 were Syrians. $^{46}$ The United Nations High Commissioner for Refugees (UNHCR) opened offices in the enclaves in July 2014, with the main motivation being the arrival of Syrians. Owing to the tightening of border closure, several migrants from African countries who had become stuck in Morocco started to move toward Algeria or Libya, and some moved south to attempt the dangerous maritime route to the Canary Islands. ${ }^{47}$ What is more, Frontex notes an increasing number of detected forged papers by West African nationals in the Casablanca airport. ${ }^{48}$ In other words, these recent developments reveal that bordering practices are operating in ways that create openings for some, closures for others, and result in shifting routes and diversifying tactics on the part of migrants.

Border closures by the EU are counterproductive in the sense that their methods, although demonstrably unethical and inefficient, are subject to reproduction. Starting in 2014, the Moroccan government built along its land border with Algeria a 150-kilometer fence "equipped with electronic sensors to prevent terrorist threats, irregular immigration, and other illegal cross-border

42 Ibid.

43 Frontex, "Annual Risk Analysis 2015," 10 (emphasis added).

44 GADEM, "Ceuta et Melilla."

45 Note that, since 2015, Syrians need a visa to legally enter Morocco.

46 GADEM, "Ceuta et Melilla."

47 Ibid., 54.

48 Frontex, "Annual Risk Analysis 2016." 
activities. ${ }^{49}$ Although not as sophisticated as its counterparts around the enclaves of Ceuta and Melilla, the Morocco-Algeria fence is clearly a product of the EU-led securitization of migration, while also being the direct outcome of a border dispute between the two countries. As suggested by Saddiqi, it is not clear whether the eradication of physical borders is dissuasive enough for trans-Saharan migrants. ${ }^{50}$ This is especially doubtful in the absence of the will to collaborate between the two countries, unlike the case in Morocco-Spain relations.

The close collaboration between the EU and Morocco has enabled the EUMorocco border to function as a "laboratory" where the external dimensions of EU migration policies can be tested and studied. ${ }^{51}$ Over time, the MoroccoSpain borders have shifted from high risk to low risk. In the context of the collaboration between Morocco and the EU and of the tightening of physical borders, criminalization and the politicization of irregular migration has been a major component of the border closure process. Enacted in 2003, Law 02-03, the Law regarding Entry and Residence of Foreigners in the Kingdom of Morocco and Irregular Emigration and Immigration has been the main document recording Morocco's willingness to subscribe to EU priorities of curtailing irregular migration. As the law's name suggests, it concerns irregular border crossings by Moroccans as well as irregular entry, stay, and exit by thirdcountry nationals - but contains few provisions regarding the human rights of migrants. Despite the fact that Moroccans are highly represented in irregular border crossings, the sub-Saharanization, and hence racialization, of irregular migration has been instrumentalized in such a way as to make the law more acceptable in the public domain. By mid-2005, the successful results of these measures in terms of decreasing the volume of clandestine migration into Spain were widespread topics in the Moroccan media, even as critiques against the treatment of migrants in Morocco accelerated. ${ }^{52}$

Issued in the context of growing national and international criticism of the treatment of irregular migrants in Morocco, a report by the Moroccan National Council of Human Rights (Conseil national des droits de l'Homme, $\mathrm{CNDH}$ ) on the human rights of foreigners in Morocco was presented to King Mohammed VI in September 2013, initiating a clear shift in national migration policies. Acknowledging that Morocco had become a land of immigration, the $\mathrm{CNDH}$

49 Said Saddiki, "Fortifying the Morocco-Algeria Border: Security Concerns and Regional Competition," paper presented at the International Conference on Borders, Walls and Violence: Costs and Alternatives to Border Fencing (Raoul Dandurand Chair at the University of Québec at Montreal, June 2-3, 2016).

50 lbid.

51 Andersson, "Time and the Migrant Other."

52 Jérôme Valluy, "Le HCR au Maroc: Acteur de la Politique Européenne d'externalisation de l'Asile," L'Année du Maghreb 3 (2007): 547-575. 
recommended a set of policies to facilitate the legal and socioeconomic integration of both asylum seekers and migrants. ${ }^{53}$ Somewhat earlier than this report, the Mobility Partnership Agreement signed with the EU in June 2013 had recommended the introduction of a national asylum law. These critiques and recommendations led to a paradigmatic change in Moroccan immigration policies. The change in the tone of officials was clear, and the public speeches of the Minister of Moroccans Abroad, Anis Birou-who began to deal with migration affairs under his mandate-underscored the radical change in the official discourse. For example, during an international meeting on the new policy, he stated that:

Morocco, because of this new policy, will save thousands of lives. We all want to prevent new Lampedusas [... This new migration policy of Morocco does not only concern Morocco [...] We believe that this is a shared responsibility; we are all assuming this responsibility in giving migrants a second chance to realize their dreams, instead of the hell of crossing the Mediterranean, to realize the Moroccan dream. ${ }^{54}$

The statement echoes other cases in the Mediterranean where border closures became legitimized within the context of the discourse of saving lives. In the case of Morocco, we also observe that, paradoxically, the introduction of integration policy-which included nearly 27,000 irregular migrants and granted residence permits as part of the first regularization campaign-can also be analyzed as an unintended outcome of border closures. While the Moroccan case of giving migrants a second chance has been seen as exemplary, their actual success in terms of the provision of protection is debatable. For instance, the Moroccan asylum law promised in the context of the new policy has yet to be enacted. Moreover, there has been skepticism as to whether the new policy approach was coupled with coercive measures along the borders. Along with the rupture from the previous approach, which criminalized the presence of migrants on Moroccan territory, continuities in securitized measures have crystalized through practices of removal. Such practices have led to severe injuries and deaths, especially along the border throughout 2014, as well as following the end of the first regularization program. Ultimately, the Moroccan case reveals that physical border closure forms an important aspect of

53 Conseil national des droits de l'Homme, $(\mathrm{CNDH})$, "Conclusions et Recommandations du Rapport: 'Etrangers et Droits de l'Homme au Maroc: Pour une Politique d'Asile et d'Immigration Radicalement Nouvelle"' (Rabat: CNDH, 2013).

54 Authors' notes from the meeting "The New Migration Policy in Morocco: Which Strategy of Integration?" organized by the Ministry in Charge of Moroccans Abroad and Migration Affairs, IOM, Confederation of Switzerland, March 11-12, 2014, Rabat, Morocco. Translation from the French by the authors. 
externalization. The case also reveals the impossibility of totally closing a border, even in cases where asylum flows are relatively smaller and bilateral cooperation is relatively higher.

\section{The case of Turkey}

A straightforward description of Turkey's geographical location and the recent history of its neighborhood may be sufficient to fully explain the country's border vulnerabilities, particularly on the Iraqi and Iranian, and recently Syrian, borders in country's southeast. Not only have these neighboring countries been sources of irregular migrants and refugees, but they also have served as transit lands for those mobilized from such distant source countries as Afghanistan, Pakistan, Somalia, and Eritrea. It is frequently confirmed that, over the last few decades, Turkey has been faced with various mixed migratory flows that have created a complex migration system involving irregular labor migrants, transit migrants, asylum seekers, refugees, and regular migrants. ${ }^{55}$ The Turkish-Greek border-with a land border of 203 kilometers as well as 2,800 kilometers of convoluted Aegean coast-has frequently been used for such crossings. In particular, over the last decades, Lesbos, Kos, and certain other nearby Greek islands in the Aegean Sea-all located just a few miles from the Turkish coast-have attracted asylum seekers, refugees, and irregular migrants. Recently, the number of irregular border crossings along the Turkish-Bulgarian border have also increased. ${ }^{56}$

Whereas immigration and asylum policies in Europe are becoming increasingly selective and restrictive, as discussed above, Turkey's related policies and practices have been both relatively selective and lax. For instance, on the one hand, Turkey still applies the geographical limitation to the 1951 Convention Relating to the Status of Refugees, and thus does not offer the right of stay to refugees originating from non-European countries, thereby pushing recognized refugees to settle in third countries. On the other hand, however, Turkey also employs somewhat liberal visa and border-crossing regimes. As a result, the country's borders are highly permeable to human mobility.

The estimated volume of border crossings through Turkey has already been documented in previous studies. ${ }^{57}$ For instance, from 1996 to 2006, almost

55 Ahmet İçduygu, "Turkey's Evolving Migration Policies: A Mediterranean Transit Stop at the Doors of the EU," in IAI Working Papers 15/31 (September 2015). http://www.iai.it/sites/default/files/iaiwp1531. pdf.

56 Frontex, "Annual Risk Analysis 2015," 6.

57 Ahmet içduygu and Deniz Yükseker, "Rethinking Transit Migration in Turkey: Reality and RePresentation in the Creation of a Migratory Phenomenon," Population, Space and Place 18, no. 4 (2012): 441-456. 
620,000 irregular migrants were apprehended in Turkey, nearly 52 percent of whom appeared to be transit migrants intending to move on to European countries. The most important source countries of migrants or asylum seekers were Iraq, Pakistan, Afghanistan, Iran, and Bangladesh. Evidence from various studies in Turkey shows that border controls in terms of the risk of arrest and length of detention appear to be a consideration for people in selecting a route, alongside other primary concerns like safety and cost. ${ }^{58}$ When, in 2012, Greece initiated very strict border control policies and practices that included the deployment of approximately 1,800 border police officers and the construction of a 10.5-kilometer fence on the border with Turkey, migrants and refugees were pushed toward more dangerous routes where they could be further exploited by smugglers. ${ }^{59}$ Restrictive border control policies on the land route shifted the flows to the Aegean Sea and to the Bulgarian border. Similarly, when in 2014 the Bulgarian government initiated the construction of a 30kilometer fence along its Turkish border, as well as enhanced operational measures such as an Integrated Border Surveillance System (IBSS) and a special border police patrol, there was a considerable decrease in the number of apprehensions at the Bulgarian land border, coupled with rising flows along the Black Sea route to Bulgaria or Romania. ${ }^{60}$ In short, it seems that even border control through the medium of fences or walls fails to limit irregular migration; instead, it merely changes the routes that people take.

It is undeniable that, once the borders have been subjected to closure policies and practices, the fluctuating and even rising figures related to irregular border crossings serve to highlight the questionable success of these policies and practices. ${ }^{61}$ From 2010 to 2014 , there was considerable fluctuation in these figures. For instance, in 2010 there were 33,000 apprehensions of irregular migrants, representing the lowest level since the early 1990s. But this figure rose to 48,000 in 2012 , then declined to 40,000 in 2013 , then again rose to 59,000 in 2014, which was followed in 2015 and 2016 by the highest numbers ever recorded, 146,000 and 175,000, respectively. In 2016, the main source countries were Syria (70,000), Afghanistan (31,000), Iraq (31,000), and Pakistan $(19,000)$. The change in the number of irregular migrants between

58 Marieke Wissink and Orçun Ulusoy, "Navigating the Eastern Mediterranean: The Diversification of Sub-Saharan African Migration Patterns in Turkey and Greece," in Understanding Migrant Decisions: From Sub-Saharan Africa to the Mediterranean Region, ed. Belachew Gebrewold and Tendayi Bloom (Oxon and New York: Routledge, 2016): 120-139; Ayşem Biriz Karaçay, "Shifting Human Smuggling Routes along Turkey's Borders," Turkish Policy Quarterly 15, no. 4 (2017): 97-108.

59 Karaçay, "Shifting Human Smuggling Routes," 103.

60 Ibid., 105.

61 These figures, indicating cases of apprehension by Turkish law enforcement authorities, have been compiled by the authors through their regular reporting for the OECD Continuous Reporting System on Migration. 
2015 and 2016 illustrates the sharp rise in the numbers of Afghans (up from 12,000 in 2014), Iraqis (up from 2,000 in 2014), and Pakistanis (up from 2,000 in 2014), even as the number of irregular crossings by Syrians remained relatively stable, showing only a small decline (from 73,422 in 2015 to 69,755 in 2016). It thus appears that, over the last decade, Turkey not only began to host over three million Syrians, but also faced an increasing number of migrants or refugees waiting for opportunities to cross the country's borders irregularly.

Since the late 1990s, Turkey's transformation into a land of immigration and transit has been very much an issue of debate in the EU. In particular, there were first the Helsinki decisions of December 1999, which declared Turkey's candidacy for EU membership. ${ }^{62}$ Second, there was the Commission's recommendations of October 2004, which announced Turkey's progress toward accession, ${ }^{63}$ while also raising new questions and concerns in terms of the country's immigration policies and practices. These debates made it clear that "in terms of Turkey, managing the new and long external borders of the EU will constitute a significant political challenge and will require large investment [...] Closer cooperation [...] shall make it easier [...] to handle migration and asylum issues in addition to [...] human trafficking of human beings." ${ }^{64}$ Consequently, the issue of "migration management" became an important component of the country's unsteady Europeanization process, particularly over the last decade. The conditionality principle of the EU accession process and the EU-Turkey membership negotiations have had an enormous impact on the transformation of the qualities and conditions of migration and asylum management in Turkey. In the early 2000s, it seemed clear that the idea of European integration was exercising a remarkable impact on Turkey's border and immigration control policies and practices. The Turkish government demonstrated a strong political will to deal with irregular migration, human trafficking, and smuggling, as well as the labor consequences for the country. There were also new legislative and administrative arrangements with this purpose in mind. 2003's Law No. 4771, for instance, contributed to the Turkish penal code and conformed to the Palermo Protocol against Trafficking in Persons by introducing into the Turkish legal system a

62 Ahmet İçduygu, "EU-ization Matters: Changes in Immigration and Asylum Practices in Turkey," in The Europeanization of National Policies and Polities of Immigration, ed. Thomas Faist and Andreas Ette (London: Palgrave Macmillan, 2007): 201-222.

63 Ahmet İçduygu and Ayşen Üstübici, "Negotiating Mobility, Debating Borders: Migration Diplomacy in Turkey-EU Relations," in New Border and Citizenship Politics, ed. Helen Schwenken and Sabine RußSattar (London: Palgrave Macmillan, 2014): 44-59.

64 "Communication from the Commission to the Council and the European Parliament: Recommendation of the European Commission on Turkey's Progress towards Accession," October 6, 2004. https:// eur-lex.europa.eu/legal-content/EN/TXT/?uri=CELEX\%3A52004DC0656. 
definition of human trafficking and the criminalization of the act of trafficking as such. What is more, further sanctions against smuggling activities were also introduced. ${ }^{65}$

The most important step fully signaling Turkey's internalization of and willingness to adopt EU-initiated migration management came in the form of March 2005's Action Plan on Asylum and Migration. This plan laid out all of the details of the associated tasks as well as a timetable for a fully-fledged migration and asylum management system compatible with the related policies and practices of the EU. During this early, energizing period of the membership negotiations with the EU, Turkish officials were initially positive about thus harmonizing the county's migration- and asylum-related legislation. However, the necessary steps to implement the indicated tasks occurred very slowly, and increasing uncertainties about Turkey's EU membership created an environment of distrust. Some Turkish authorities raised concerns that, should Turkey harmonize its legislations and policies with the EU without becoming a full member, the country would simply become a "dumping ground" for irregular migrants apprehended on EU territories. ${ }^{66}$ As a result, based on its commitments to the 2005 Action Plan on Asylum and Migration, Turkey slowly took steps toward drafting a law on foreigners and a law on asylum, which ultimately led to the enactment of April 2013's Law on Foreigners and International Protection.

The environment of distrust also had a clear negative impact on negotiations for the Readmission Agreement, which was signed in December 2013, and on the opening of visa liberalization dialogue, which has yet to become fully operational. In the meantime-and again in order to harmonize its immigration-related policies and practices to the EU's regulations in general, as well as to increase the efficiency of its border control regime-Turkey has signed readmission agreements with 14 more states and proposed to sign readmission deals with another 14 states, including such major source and transit countries as Afghanistan, Iran, and Iraq. ${ }^{67}$ Turkey's generous reception and settlement policies regarding Syrian refugees marked a new stage in the migration diplomacy between the EU and Turkey. Initially, these

65 Other measures related to closures included the adoption of the new Law on Work Permits for Foreigners (No. 4817, dated 2003) and the amendment to the Citizenship Law of 2003, which introduced a three-year prohibition on applying for Turkish citizenship in the case of a foreigner marrying a Turkish national, in order to prevent migration to Turkey via false marriages.

66 See Birce Demiryontar, "The Shaping of Turkish Migration Policy: Competing Influences between the European Union, International Organisations and Domestic Authorities" (Ph.D. dissertation, Sussex University, 2016).

67 See Emine Kart, "Turkey Seeks Readmission Deals with Iraq, Iran," Hürriyet Daily News, September 12, 2016. http://www.hurriyetdailynews.com/turkey-seeks-readmission-deals-with-iraq-iran-97699. 
policies created a wide range of praise from European officials-but in later years, when Europe was faced with the spillover effect of Syrian refugee flows, Turkey again came to be perceived as a guardian of the Schengen area. In the summer and fall of 2015, irregular border crossings from Turkey to the EU increased, with heavy traffic moving through Greece. This was perceived as a period of "crisis," as many refugees from Syria as well as migrants from other countries mobilized to enter Europe. This event later resulted in a revitalization of migration diplomacy between Turkey and the EU, which then resulted in the introduction of several instruments for border closures and in externalization measures. In 2016, a statement between the EU and Turkey-commonly known as the "Turkey-EU Deal"-ensured (in exchange for $3+3$ billion Euro to the Turkish government) that all those who arrived in Greece "illegally" would be returned to Turkey, thereby delegating control of the EU's southeastern borders to Turkish authorities. This was certainly not the first time that the EU and Turkey had debated and concluded on procedures for border arrangements: migration diplomacy between the two entities already had a relatively long history. ${ }^{68}$ While the legal problems inherent in the EU. Turkey statement of 2016 have long been discussed, the statement is really best understood as a continuation of the externalization of EU migration and border policies.

The EU-Turkey statement is considered an effective measure for migration control because it succeeded in bringing down the number of migrants arriving in Greece. However, there are also studies showing that the decline in the number of arrivals actually predates the EU-Turkey agreement, and that, if the agreement has indeed had any effect at all, it has actually been the interruption of this decline. ${ }^{69}$ Furthermore, it is also very much debated whether the 2016 statement comes at a cost to the values that are considered fundamental to international asylum rights and refugee protection regimes. ${ }^{70}$ It was within this climate of processes of securitization and externalization that Turkey suspended its open border policy with Syria. As has been widely covered in the media, the Turkish government constructed a wall along the Syrian border, and another is planned along the Turkey-Iran border, with the goal of stopping irregular border crossings, including the arrival of people with asylum claims in

68 İçduygu and Üstübici, "Negotiating Mobility”; Ahmet İçduygu and Damla B. Aksel, "Two-to-Tango in Migration Diplomacy: Negotiating Readmission Agreement between the EU and Turkey," European Journal of Migration and Law 16, no. 3 (2014): 337-363.

69 Thomas Spijkerboer, "Fact Check: Did the EU-Turkey Deal Bring down the Number of Migrants and of Border Deaths?," Border Criminologies, September 28, 2016. https://www.law.ox.ac.uk/researchsubject-groups/centre-criminology/centreborder-criminologies/blog/2016/09/fact-check-did-eu.

70 Collett, Elizabeth, "The Paradox of the EU-Turkey Refugee Deal," MPI Commentary, March 2016. https://www.migrationpolicy.org/news/paradox-eu-turkey-refugee-deal. 
need of protection. ${ }^{71}$ The closing and externalizing activities surrounding the EU-Turkey borders in recent years create not only riskier conditions for people on the move, but also bottlenecks within so-called transit countries, especially for refugee-receiving countries like Turkey.

\section{Concluding remarks}

Since the late 1990s, we have witnessed the conceptualization of human mobility as a security problem for nation-states. In this context, the state of exceptions within the borders of Europe has emerged just outside of Europe's borders as well, with the Mediterranean basin at the center of these developments. Border closures in the basin produced new spaces where borders are often fenced, immigration securitized, and border crossings and those who facilitate such crossings criminalized. In this context, the construction of walls and fences and the emergence of readmission agreements and other restrictive policies in Europe and its neighborhood have rapidly expanded to peripheral countries. As a consequence, various types of migrants who cross the Mediterranean basin find themselves in a state of insecurity and uncertainty. This is due in large part to the policies and practices of border closures and the related externalization activities of European agencies and their counterparts in the EU's neighboring countries.

All of these developments have become subject to the migration diplomacy conducted between neighboring countries, such as Morocco and Turkey, and the EU (or its member states). ${ }^{72}$ Morocco and Turkey have comparable geographical positions with respect to and close relations with the EU, which has led to their transformation from spaces of "transit" into spaces aiming to stop transit migration, or, as described elsewhere, "anti-transit." cases at opposite ends of the Mediterranean, this article has argued that border closures may indeed reduce the number of those crossing particular borders, but only under certain temporary and sui generis conditions: if the overall volume of flows is not enormous; if the push factors are sporadic; and if the closure practices are coupled with cooperative efforts entailing the development of legal and logistical infrastructures in neighboring countries. This analysis of recent developments on the Turkey-Greece and Morocco-Spain borders reveals that border closures will not work without legal closures; that is, without legal and institutional mechanisms underpinning the actual physical closure of the border.

71 See Ida Marie Vammen and Hans Lucht, "Refugees in Turkey Struggle as Border Walls Grow Higher," DIIS Policy Brief, December 18, 2017. https://www.diis.dk/node/11965.

72 İçduygu and Üstübici, "Negotiating Mobility."

73 Üstübici, "The Governance of International Migration," 53-54. 
However, even in the most suitable cases, such as Morocco, border closures remain scattered. Closing the physical border may go hand in hand with other openings, such as the case of regularization in Morocco, thus supporting our nonlinear conceptualization of border closure.

In the context of Turkey, potential EU membership status created the incentive for cooperative efforts toward border controls. However, border closures on Turkey's part have been erratic and a source of distrust about the prospect of membership. At the same time, asylum flows directed to Turkey in any case rendered closure impossible. It is within precisely this context that there have been some relative and short-term successes regarding closures and externalization policies on the Morocco-Spain and Turkey-Greece borders. Over the last several decades, even when these borders have been under heavy surveillance and control, unauthorized crossings never ended. In this sense, this article furthers William Walters' call to engage with temporalities in studying borders at both the macro and the micro level. ${ }^{74}$ It appears that, rather than causing a considerable long-term decline in the overall volume of irregular migration, border closures end up depicting borders as the main objects to be protected: they create a sense of urgency and an ephemeral illusion of the possibility of fully closed borders.

This article once more confirms that, by their very nature, borders and border crossings constitute unresolved issues of governance both within and between states. On the one hand, countries like Turkey and Morocco, faced with pressure by the EU to deal with irregular flows, require certain control mechanisms and law enforcement capacities. On the other hand, though, developing countries with scarce resources cannot realistically be expected to comply with such external demands, especially without access to the necessary gains, resources, and assistance. As such, this dilemma reminds us of the necessity of responsibility sharing rather than responsibility shifting, as well as of the need to elaborate upon the root causes of the flows rather than on their consequences in the framework of the global governance of migration and asylum flows. Finally, the shortcomings of security- and state-based policieswhich are determining factors in the formulation and application of border closures based on externalization tendencies-are to be questioned. It has already been emphasized how all such restrictive arrangements create enormous costs in terms of human security, since they often violate the fundamentals of individuals' and families' rights to mobility by rendering them responsible for their own misery, as well as violating the very premises of international protection regimes.

74 William Walters, "Live Governance, Borders, and the Time-Space of the Situation: EUROSUR and the Genealogy of Bordering in Europe," Comparative European Politics 15, no. 5 (2017): 794-817. 


\section{References}

Andersson, Ruben. "Europe's Failed 'Fight' against Irregular Migration: Ethnographic Notes on a Counterproductive Industry." Journal of Ethnic and Migration Studies 42, no. 7 (2016): 1055-1075.

- "Time and the Migrant Other: European Border Controls and the Temporal Economics of Illegality." American Anthropologist 116, no. 4 (2014): 795-809.

Asociación Pro Derechos Humanos de Andalucía (APDHA). "Derechos Humanos en la Frontera Sur 2009." Seville: APDHA, 2010.

Bigo, Didier. "Death in the Mediterranean Sea: The Results of the Three Fields of Action of European Union Border Controls." In The Irregularization of Migration in Contemporary Europe: Detention, Deportation, Drowning. Edited by Yolande Jansen, Robin Celikates, and Joost de Bloois. London: Rowman and Littlefield, 2015. 55-70.

Carling, Jørgen and María Hernández-Carretero. "Protecting Europe and Protecting Migrants? Strategies for Managing Unauthorised Migration from Africa." The British Journal of Politics \& International Relations 13, no. 1 (2011): 42-58.

Cassarino, Jean-Pierre. "Informalising Readmission Agreements in the EU Neighbourhood." The International Spectator 42, no. 2 (2007): 179-196.

Collyer, Michael. "In-Between Places: Trans-Saharan Transit Migrants in Morocco and the Fragmented Journey to Europe." Antipode 39, no. 4 (2007): 668-690.

Conseil national des droits de l'Homme, (CNDH). "Conclusions et Recommandations du Rapport: 'Etrangers et Droits de l'Homme au Maroc: Pour une Politique d'Asile et d'Immigration Radicalement Nouvelle'." Rabat: CNDH, 2013.

De Genova, Nicholas. "Extremities and Regularities: Regulatory Regimes and the Spectacle of Immigration Enforcement." In The Irregularization of Migration in Contemporary Europe: Detention, Deportation, Drowning. Edited by Yolande Jansen, Robin Celikates, and Joost de Bloois. London: Rowman and Littlefield, 2015. 3-14.

Delanty, Gerard. "Borders in a Changing Europe: Dynamics of Openness and Closure." Comparative European Politics 4, no. 2-3 (2006): 183-202.

Frontex. "Annual Risk Analysis 2015." Warsaw: Frontex European Agency for the Management of Operational Cooperation at the External Borders of the Member States of the European Union, 2015.

. "Annual Risk Analysis 2016." Warsaw: Frontex European Agency for the Management of Operational Cooperation at the External Borders of the Member States of the European Union, 2016.

GADEM (Le Groupe antiraciste de défense et d'accompagnement des étrangers et migrants). "La Chasse aux Migrants aux Frontières Sud de l'UE Conséquence des Politiques Migratoires Européennes: L'exemple des Refoulements de Décembre 2006 au Maroc." Rabat: GADEM, 2007.

GADEM, Migreurop, La Cimade, and APHDA. "Ceuta et Melilla: Centres de tri à ciel ouvert aux portes de l'Afrique." GADEM 2015. http://www.migreurop.org/IMG/pdf/fr_rapportconjoint_ceutamelilla_ decembre2015.pdf.

Geddes, Andrew. Immigration and European Integration: Towards Fortress Europe? European Policy Research Unit Series. Manchester, UK: Manchester University Press, 1999.

Grassiani, Erella and Michiel Swinkels. "Introduction: Engaging with Borders." Etnofoor 26, no. 1 (2014): 7-12.

Huysmans, Jef. The Politics of Insecurity: Fear, Migration and Asylum in the EU. London and New York: Routledge, 2006.

Içduygu, Ahmet. "EU-ization Matters: Changes in Immigration and Asylum Practices in Turkey." In The Europeanization of National Policies and Polities of Immigration. Edited by Thomas Faist and Andreas Ette. London: Palgrave Macmillan, 2007. 201-222.

. "The Politics of Irregular Migratory Flows in the Mediterranean Basin: Economy, Mobility and 'Illegality'.' Mediterranean Politics 12, no. 2 (2007): 141-161.

. "Turkey's Evolving Migration Policies: A Mediterranean Transit Stop at the Doors of the EU." In IAI Working Papers 15/31. September 2015. http://www.iai.it/sites/default/files/iaiwp1531.pdf.

Içcduygu, Ahmet and Damla, B. Aksel. "Two-to-Tango in Migration Diplomacy: Negotiating Readmission Agreement between the EU and Turkey." European Journal of Migration and Law 16, no. 3 (2014): 337-363. 
İçduygu, Ahmet and Ayşen Üstübici. "Negotiating Mobility, Debating Borders: Migration Diplomacy in Turkey-EU Relations." In New Border and Citizenship Politics. Edited by Helen Schwenken and Sabine Ruß-Sattar. London: Palgrave Macmillan, 2014. 44-59.

İçduygu, Ahmet and Deniz Yükseker. "Rethinking Transit Migration in Turkey: Reality and Re-Presentation in the Creation of a Migratory Phenomenon." Population, Space and Place 18, no. 4 (2012): 441-456.

Johnson, Corey and Reece Jones. "The Biopolitics and Geopolitics of Border Enforcement in Melilla." Territory, Politics, Governance 6, no. 1 (2018): 61-80.

Karaçay, Ayşem Biriz. "Shifting Human Smuggling Routes along Turkey's Borders." Turkish Policy Quarterly 15, no. 4 (2017): 97-108.

Kausch, Kristina and Richard Youngs. "The End of the 'Euro-Mediterranean Vision'." International Affairs 85, no. 5 (2009): 964-975.

Lavenex, Sandra. "Shifting Up and Out: The Foreign Policy of European Immigration Control." West European Politics 29, no. 2 (2006): 329-350.

Mountz, Alison and Jenna M. Loyd. "Constructing the Mediterranean Region: Obscuring Violence in the Bordering of Europe's Migration 'Crises'." ACME: An International E-Journal for Critical Geographies 13, no. 2 (2014): 173-195.

Pallister-Wilkins, Polly. "The Tensions of the Ceuta and Melilla Border Fences." In EurAfrican Borders and Migration Management. Edited by P. Gaibazzi, S. Dünnwald, and A. Bellagamba. New York: Palgrave Macmillan, 2017. 63-81.

Pollak, Johannes and Peter Slominski. "Experimentalist but Not Accountable Governance? The Role of Frontex in Managing the EU's External Borders." West European Politics 32, no. 5 (2009): 904-924.

Rumelili, Bahar and Sibel Karadağ. "Göç ve Güvenlik: Eleştirel Yaklaşımlar.” Toplum ve Bilim 140 (2017): 69-92.

Saddiki, Said. "Fortifying the Morocco-Algeria Border: Security Concerns and Regional Competition." Paper presented at the International Conference on Borders, Walls and Violence: Costs and Alternatives to Border Fencing. Raoul Dandurand Chair at the University of Québec at Montreal, June 2-3, 2016.

Spijkerboer, Thomas. "Fact Check: Did the EU-Turkey Deal Bring down the Number of Migrants and of Border Deaths?" Border Criminologies, September 28, 2016. https://www.law.ox.ac.uk/researchsubject-groups/centre-criminology/centreborder-criminologies/blog/2016/09/fact-check-did-eu.

Sterkx, Steven. "The External Dimension of EU Asylum and Migration Policy: Expanding Fortress Europe." In Europe's Global Role: External Policies of the European Union. Edited by Jan Orbie. Aldershot: Ashgate, 2008. 117-138.

Üstübici, Ayşen. The Governance of International Migration: Irregular Migrants' Access to Right to Stay in Turkey and Morocco. Amsterdam: Amsterdam University Press, 2018.

. "Political Activism between Journey and Settlement: Irregular Migrant Mobilisation in Morocco." Geopolitics 21, no. 2 (2016): 303-324.

—. "Türkiye'de Göç Politikaların Dönüşümü: Yasadışılığın Uluslararası Üretiminden Makbul Yabanciya?" Toplum ve Bilim 140 (2017): 106-122.

Valluy, Jérôme. "Le HCR au Maroc: Acteur de la Politique Européenne d'externalisation de l'Asile." L'Année du Maghreb 3 (2007): 547-575.

Walters, William. "Live Governance, Borders, and the Time-Space of the Situation: EUROSUR and the Genealogy of Bordering in Europe." Comparative European Politics 15, no. 5 (2017): 794-817.

Wissink, Marieke and Orçun Ulusoy. "Navigating the Eastern Mediterranean: The Diversification of SubSaharan African Migration Patterns in Turkey and Greece." In Understanding Migrant Decisions: From Sub-Saharan Africa to the Mediterranean Region. Edited by Belachew Gebrewold and Tendayi Bloom. Oxon and New York: Routledge, 2016. 120-139.

Zapata-Barrero, Ricard and Nynke De Witte. "The Spanish Governance of EU Borders: Normative Questions." Mediterranean Politics 12, no. 1 (2007): 85-90. 